\title{
Perspecive
}

\section{Education in Medicine as a component of Modern Science; restoring the balance ${ }^{\S}$}

\author{
Arseculeratne $\mathrm{SN}^{1 *}$ \\ ${ }^{1}$ Emeritus Professor, Faculty of Medicine, University of Peradeniya \\ $\S$ Some of the contents of this essay were presented orally at the IMEC2010 conference - The Future of Medical \\ Education - at the International Medical University, Kuala Lumpur, Malaysia, 24 - 26 March 2010.)
}

\begin{abstract}
Since 1871 when the Colombno Medical College was instituted, the education of undergraduates and postgraduates in medicine, over the suceeding decades, had the prime aim of producing doctors who could deliver health care. This was the continuation of British colonial policy. The establishment of the University of Ceylon in 1942 continued this orientation, while in later decades and in contemporary times, the place of medicine as a component of modern science has been ignored. If the major function of a modern university in the sciences, is to establish a scientific culture, an onverhaul of the system of medical education is essential. In instruction and evaluation, the inordinately heavy emphasis on factual content needs supplementation with the sponsoring of creative, integrated thinking and with discussions on the historical and philosophical aspects of medicine as a component of modern science, instead of considering it merely as a uitilitarian task, that would produce only medical technicians, and not medical scientists, whom our country needs.
\end{abstract}

Key words: Medical education, The history and philosophy of modern science

Copyright: $\bigcirc 2014$ Arseculeratne SN.This is an open access article distributed under the Creative Commons Attribution License, which permits unrestricted use, distribution, and reproduction in any medium, provided the original work is properly cited.

\footnotetext{
*Correspondence: chubby@sltnet.lk
}

Cite this article as:Arseculeratne SN. Education in Medicine as a component of Modern Science; restoring the balance. Anuradhapura Medical Journal 2014;8(2):45-48.

DOI: http://dx.doi.org/10.4038/amj.v8i2.7526 
My comments in this essay arise from fifty-two years of teaching-experience with medical undergraduates and postgraduates in Sri Lankan and Malaysian universities. Specifically I refer to a question - Are clinicians, scientists? - asked by a Senior Professor of Medicine, after we listened to presentations at an Annual Research Sessions of The Kandy Society of Medicine, at Peradeniya.

Historical and present status of 'medical education' in SL (Arseculeratne 1995, Urgaoda 1987).

Education in modern medicine has been held in Sri Lanka (Ceylon) since the mid 1800s. Overall, its content has been that of Western medical education, especially British. The aim of medical education during the British period was to produce local doctors who filled subordinate posts in the department of health. Over the decades curricular changes were made to reckon with the increasing content of medical knowledge and the contemporary curriculum still maintains that aim of producing a 'practising' or 'basic' doctor, with methods that are used in current 'medical education' - learning objectives, small group discussions, and drafting of objective questions. The British administration in health devoted attention to medical research, for example with Sir Aldo Castellani who made original contributions on tropical diseases, Nicholls on nutrition, and John Davy with 152 papers, and books on geology, pathology, anthropology, and sociology (Uragoda 1987); undergraduate medical education in later and recent decades, and even in the current decade, had only meager attention to research methodology, which was restricted to academic and laboratory staff, while medical education equipped the students with a knowledge of the craft of medicine but not its status as an important component of the scientific enterprise. The historical and philosophical basis of medical science as a component of modern science that had been regarded as the greatest intellectual enterprise of man, was almost entirely ignored. I recall the view of R.B. Hunter writing on one of the functions of a modern university, in the sciences, that of establishing $a$ scientific culture.

\section{What is missing}

The view of the author is that this is a serious omission in the general content of contemporary medical education in Sri Lanka (and perhaps in other countries of South Asia), in the disregard for medicine as an applied component of modern science. Consequently the teaching of medicine (the basic sciences and the clinical sciences) deals with the facts and the statement of current theories of medical science but not with the historical, intellectual and philosophical aspects of science of which medicine forms an applied component, and which led to the establishment of those theories. What is also missing is the emphasis on innovative thinking, noting that the development of modern science resulted from innovative and creative thought; the history of the growth of modern science amply illustrates this. The adverse impact of this lack of these modes of thinking is on creative and innovative research that is urgently required to investigate the medical problems that still await resolution, and to cope with the changing patterns of epidemiology. For example, it was a research orientation with original thinking, as an individual talent, that enabled a local medical scientist to unravel the pathogenesis of neuropathy of obscure origin in agricultural regions. Examples of current unsolved problems, according to my clinical colleagues, that will benefit from a capability for innovative research are: Is there a role for immune reactions in the rising early death rate in Dengue? Is there central neurological dysfunction resulting in deep coma apart from the well-known peripheral neuromuscular paralysis in krait (snake) envenomation? What is the pathogenesis of skin necrosis, apart from the familiar skin rashes in rickettsial diseases? What is the pathogenesis of Parkinsonism in the rickettsioses and in Chikungunya fever? These diseases are currently pressing medical problems in the country. On the other hand, I could cite at least three examples of publications in prestigious western journals of research done in an Asian country, which though based on the use of sophisticated apparatus, ended with indefensible conclusions, the most egregious error of which stated that the cause of rhinosporidiosis is not the endospore seen by every author over the last one hundred and eighteen years, but starch from the excessive eating of tapioca; I use that as an example of the phenomenon which I term Idola machinorum, the fondness for sophisticated, technical procedures akin to the original Idola quantitatis, of Peter Medawar (1984) who referred to the use of impressive statistics, to cover the nakedness of bald and fruitless experimentation.

As far as the lack of discussions on the philosophy of modern science in contemporary medical or undergraduate education in this country is concerned, this deficiency appears to occur even in scientifically advanced countries such as the UK. I had thought that this phenomenon of the neglect of the inclusion of the history and philosophy of modern science in our country as in, I believe, other Asian countries was due to the historical fact that our countries, though they had an impressive record of the pursuit of rudimentary science in ancient times, did not participate in the growth of modern science which, indisputably, occurred in western Europe over the last three hundred years. But reading James Williams [4] commenting on this lack, even in Britain, in his article, "What makes science 'Science?", after a study of the situation in the UK, commented: "Graduates from arrange of science disciplines and from a variety of universities in Britain and around the world, have a poor grasp of the meaning of simple terms and are unable to provide appropriate definitions of key scientific terminology". This comment highlights another deficiency of contemporary Lankan medical education, that promoting an understanding of scientific concepts has been overwhelmed by the transfer of factual knowledge; correspondingly, formative and summative evaluation has been largely on factual recall with a little attention on problem solving based on factual knowledge; there has 
been little emphasis on creative or innovative thinking. Williams continues: "The majority had high quality degrees and some had doctorates in a science discipline, so it wasn't that they were not well qualified in science. It was just that their study of science had been utilitarian, a means to an end with the end being a practising scientist"; this situation is similar to the orientation of medical education in British colonial and contemporary times. The contemporary lack of appreciation of the intellectual aspects of medicine as a component of modern science could also be due to the overwhelming sway of modern medical educational technology that has seduced the personnel involved in curricular reform. The phrase "restoring the balance" in the title of this essay was succinctly put by neurologist Walshe (1948): "Some generality of understanding is the essence of a civilised culture, and is a crying need in medicine, and we must seek it earnestly if we are not to decline to the level of craftsmen and technicians."

\section{What can be done}

It is concluded that only an understanding of the processes of scientific discovery will equip the students for a productive medical career by preparing the foundation for assimilating the later instruction in the craft of medical science and for engaging in effective medical research; the essential components of the foundation are the historical and philosophical bases that underlay scientific discoveries, the methodologies of creative scientific research, the logic of scientific inference, the nature of scientific hypotheses, theories and laws, the validation of theories, falsification, the idea of causality and the use of proper controls, the design of field, clinical and laboratory research, and experiments, the synergistic relationship between basic and applied research, and the limitations of science; these topics, as well as professionalism, values the team approach and the sponsoring of creative thinking on the part of the student, have no place in the contemporary Sri Lankan undergraduate medical curriculum. On the important topic of "causality" which is the central concern in the aetiology and pathogenesis of disease, Walshe (1948) referred to it "... in terms of Aristotelian modes of causation - material, formal, efficient, and final - that is, an aetiological analysis. In relation to the core of this essay, which is the relationship of medicine to modern science and its philosophy, he continued: "This is essentially the method of science, but who would deny that the gifts of insight, the ability to discern and develop analogies, to detect patterns and sequences, and to interpret logically, constitute intellectual arts that vary in their presence and degree of richness from individual to individual. This artistry, I submit, is an integral element in scientific thought and activity at its best ". I had thought that discussing this subject during my years on the staff in the Peradeniya Faculty of Medicine, was akin to flogging a dead horse, but I was encouraged to see recently that after many discussions with a senior academic member of our faculty on this topic, a slot titled
"Scientific thinking" has been added to the new curriculum; I hope this trend continues.

With teaching oriented towards conceptual understanding of medical science in the early years, the utilitarian aspects of medicine will need more attention in the final and postgraduate years; this could be made possible by reorienting medical education to include the bases of medicine as science, either as a separate component titled the nature of the scientific enterprise, or incorporated into each segment and topic of the medical curriculum. What our students need is an over-arching understanding of the nomothetic bases of science and of medical science, of how they were achieved, and the long and tortuous course that led to that achievement. Two examples of such integration are:

(i) Complement is an important complex-component of immunological reactions that feature in hypersensitivity states, autoimmune diseases, and defence against pathogens. The description of the discovery of Complement was graphically given in that remarkable book General Pathology which consisted of lectures to Oxford undergraduates by the staff of the Sir William Dunn School of Pathology, when Nobel laureate Sir Howard Florey was its Head. It encompasses experimentation, the derivation of valid conclusions, the cumulative nature of sequential basic discoveries that led to the formulation of paradigms, the integrated view of bacteriology and immunology, the synergistic researches of four creative scientists, the specificity of immune reactions, a touch of etymology, and of course the history of immunology. It is worth quoting in full: "In 1893, Buchner reported that fresh serum was able to kill certain bacteria but that it lost this property on heating at $55^{\circ} \mathrm{C}$. $\mathrm{He}$ attributed the bactericidal action of serum to a heatlabile constituent which he called alexine (from $\alpha \lambda \varepsilon \zeta_{\zeta} \varepsilon \mathrm{v}=$ ward off). A year later Pfeiffer described the dissolution of cholera vibrios by the fresh serum of guinea pigs immunized with heated vaccines, and showed that the reaction was specific, and could be correlated with protection against infection in both actively and passively immunized animals. In 1895, Bordet showed that two factors were required for this reaction: one was a thermostable factor present in the antiserum, while the other, which appeared to be alexine, was inactivated by heating to $55{ }^{\circ} \mathrm{C}$ for half an hour and was present in normal serum. Alexine is now usually called Complement, a term introduced by Ehrlich". This is an example, both of an imaginative text-book and the opportunity for a creative, literate teacher to use that kind of integration in teaching.

(ii) Dengue is an important public health problem in contemporary Sri Lanka, with high morbidity and mortality. The contemporary theory on the pathogenesis of Dengue shock syndrome is based on the mediation of immune responses. The proximate pathogenetic agents are cytokines liberated from virus-invaded cells. The cytokines recall the old theory of "Horror autotoxicus" ('self-' or 'auto-intoxication') of the versatile and creative Paul Ehrlich that lay ignored for several decades. The discussion of the pathogenesis of Dengue Shock 
Syndrome and Dengue fever can advantageously be based not only on the contemporary knowledge of the cytokines involved but also on the evolving concept of their role in Dengue fever in relation to the ideas of Ehrlich, and the basis of his formulation of the theory of 'autointoxication'.

These ideas have been expressed earlier; neurologist Walshe wrote (1948): "Yet we must surely aim at the highest degree of understanding of the foundations of our thoughts and actions, and I submit that the capacity to advance knowledge materially and to develop a due critical faculty are both impossible on the plane of "practical common sense," and to be content to dwell exclusively thereon means that we must inevitably decline to the level of craftsmen and technicians, and our profession to a chaotic medley of technologies"..... "Yet the need for rebuilding the foundations of medicine was never greater than to-day, when we are being swept aside along a spate of new knowledge and new techniques, and have so little time for their due contemplation and integration".

\section{Conclusion.}

In summary, the author urges education in medicine not merely as a craft with utilitarian ends, but as an important component of science with an intellectual background that includes the history and philosophy of modern science, and that the contemporary emphasis on factual recall in teaching and evaluation should be modified to consider conceptual understanding (Cole 1984) as a vital avenue for the acquisition of valid knowledge. On this aspect, Williams in Britain commented: "A basic course in the history and philosophy of science should be a compulsory element of an undergraduate degree in any science discipline".

\section{Funding}

None

\section{Competing Interests}

None

\section{References}

1. Arseculeratne SN. 1995. The Faculty of Medicine. In: The University system of Sri Lanka. K. M. de Silva \& G. H. Peiris eds. ICES, The Leverhulme Trust and Friedrich Ebert Stiftung, Colombo.

2. Uragoda CG. 1987. A history of medicine in Sri Lanka-from the earliest time to 1948. Sri Lanka Medical Association, Colombo.

3. Arseculeratne SN. 1995. The Faculty of Medicine. In: The University System of Sri Lanka. Vision and Reality. ICES Sri Lanka Studies Series. de Silva KM, Peiris GH eds.. The Leverhulme Trust and Friedrich Ebert Stiftung, Colombo. http://eric.ed.gov/?id=ED396600

4. Medawar P. Pluto’s Republic. Oxford: Oxford University Press. 1984.

5. Williams James. What Makes Science 'Science'?.The Scientist.2008. http://www.the-scientist.com/?articles.view/articleNo/26768/title/What-Makes-Science--Science--/

6. Walshe FMR. The structure of medicine and its place among the sciences ((The Harveian Oration, 1948.). Livingstone:Edinburgh.1948

7. Cole KC. The essence of understanding. Discover 1984.5:

\section{Submit your next Manuscript to Anuradhapura Medical Journal}

Submit your manuscript at www.sljol.info/index.php/AMJ/ 